\title{
New finding of Giardia intestinalis (Eukaryote, Metamonad) in Old World archaeological site using immunofluorescence and enzyme-linked immunosorbent assays
}

\author{
Matthieu Le Bailly $/{ }^{1} /{ }^{+}$, Marcelo LC Gonçalves ${ }^{2,3}$, Stéphanie Harter-Lailheugue, Frédéric Prodéo ${ }^{4}$, \\ Adauto Araujo ${ }^{3}$, Françoise Bouchet \\ Université de Reims, EA 3795, UFR de Pharmacie, Laboratoire de Paléoparasitologie, CNRS UMR 5197, 51, rue Cognacq-Jay, 51096 \\ Reims, France ${ }^{1}$ Muséum National d'Histoire Naturelle, Paris, France ${ }^{2}$ Universidade de Fortaleza, Fortaleza, CE, Brasil ${ }^{3}$ Escola Nacional de \\ Saude Publica-Fiocruz, Rio de Janeiro, RJ, Brasil ${ }^{4}$ Institut National de Recherches Archéologiques Préventives, Paris, France
}

In this study, nine organic sediment samples from a medieval archaeological site at Pineuilh, France, were examined for Giardia intestinalis using two commercially available immunological kits [enzyme-linked immuno sorbent and immunofluorescence (IFA) assays]. Both techniques detected G. intestinalis in one sample, dated to 1,000 Anno Domini. This is the first time IFA was successfully used to detect protozoa in Old World archaeological samples. Such immunological techniques offer important perspectives concerning ancient protozoa detection and identification.

Key words: paleoparasitology - ELISA - IFA - Giardia intestinalis

Detection of protozoa in ancient faeces (coprolites) still poses a challenge to scientists interested in parasitic disease and host-parasite interaction evolution, because protozoan cysts are less resistant to taphonomic process than helminth eggs (Gonçalves et al. 2005). However, by applying immunological techniques, it is possible to overcome this limit. Many results published since the 1980s prove the reliability of immunology to detect protozoan infections in ancient populations. These findings concern blood protozoa such as Trypanosoma cruzi (Fornaciari et al. 1992) or Plasmodium falciparum (Miller et al. 1994, Cerutti et al. 1999), and intestinal protozoa such as Entamoeba histolytica (Fouant et al. 1982, Gonçalves et al. 2004, Le Bailly \& Bouchet 2006, Le Bailly et al. 2006). Giardia intestinalis has also been found in archaeological samples mainly coming from New World settings. Faulkner et al. (1989) detected G. intestinalis in a coprolite from the Big Bone Cave site, Tennessee, USA, dated to the III century BC, using immunofluorescence assay (IFA). Allison et al. (1999) then Ortega and Bonavia (2003) found both G. intestinalis and Cryptosporidium parvum, using IFA and enzyme-linked immunosorbent assay (ELISA) on coprolite samples from pre-Columbian (XI century BC to XV century AD) and Peruvian mummies (XXIV century $\mathrm{BC}$ to IX century AD). Gonçalves et al. (2002) detected G. intestinalis in archaeological samples, coprolites and sediments, from different sites and different periods of time, using ELISA technique. So far, the oldest finding

Financial support: CNRS, INRAP, Ile-de-France region, Capes/Cofe-

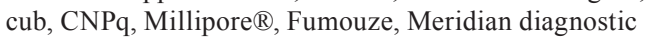
+ Corresponding author: matthieu.lebailly@univ-reims.fr Received 27 February 2008

Accepted 8 May 2008 of $G$. intestinalis in archaeological sites was reported by Le Bailly (2005), examining samples from the European medieval site of Chevennez (VII-IX centuries AD), Switzerland, by ELISA. Although intestinal protozoan infections have been recorded in different New World archaeological sites, little is know about their ancient distribution in Old World.

\section{MATERIALS AND METHODS}

To compensate the lack of study on giardiasis in Old World and to continue developing the use of immunology in paleoparasitology, nine sediment samples (S1 to S9) coming from humid habitation layers from "La Mothe", a French medieval site (X-XI centuries AD), were studied for the first time to test the presence of G. intestinalis using two commercially available immunological assays. The first, the MeriFluor Crypto \& Giardia test (Meridian Bioscience, Cincinnati, OH, USA), is an IFA to detect Cryptosporidium sp. and G. intestinalis in actual stool specimens, based on monoclonal antibodies (Garcia et al. 1987, Aldeen et al. 1995). The second, Giardia II test (TechLab, Inc., Blacksburg, VA, USA), is an immuneenzymatic kit which allows the qualitative detection of a cyst wall antigen of $G$. intestinalis in faecal specimens (Aldeen 1998, Boone et al. 1999).

The regular process we apply for archaeological sample rehydration uses a trisodic phosphate and glycerinated water solution in which some drops of formalin are added to avoid fungi and bacteria development (Le Bailly 2005). To avoid modifications of antibody/antigen link reactions due to the formalin, archaeological sample were rehydrated only using ultrapure water (Millipore ${ }^{\circledR}$ ) and stored in a refrigerator at $2-5^{\circ} \mathrm{C}$ to prevent microorganism development. Aliquots from the rehydrated samples were used in the immunological assays. Both direct IFA and ELISA were performed according to the manufacturer's instructions. 


\section{RESULTS AND DISCUSSION}

Only one sample (S1) was positive for $G$. intestinalis antigen by ELISA and direct IFA. Under UV microscopy, $\mathrm{S} 1$ yielded fluorescent ovoid elements with size of $15 \times 8 \mu \mathrm{m}$. These elements were identified as $G$. intestinalis cysts (Figure). Other samples were negative for $G$. intestinalis in both tests. The nine samples were negative for Cryptosporidium sp. antigen detection by IFA.

The presence of $G$. intestinalis in S1 can be attributed to human or animal faecal pollution. However, the presence of the human specific nematode Enterobius sp. eggs in the sample, identified during a previous regular microscopically analysis, proves the presence of a faecal pollution of human origin.

G. intestinalis is a faecal-oral transmitted flagellate protozoan transmitted by cyst ingestion after faecal food contamination (Mehlhorn 2001). Trophozoites are liberated in the small intestine after excystation, and attach to the small intestine epithelium, causing digestive symptoms of variable importance, among which diarrhoea is the main associated (Nozais et al. 1996, Gentilini 1999, Acha \& Szyfres 2005).

Although the specificity of the ELISA Giardia II test had been evaluated using faecal specimens containing many other parasites, including E. histolytica, Ascaris lumbricoides, Trichuris trichiura, and ancylostomidae, false-positive results can not totally be excluded. IFA, on the other hand, has the advantage to allow direct observation of cysts under optical microscopy. According to the manufacturers, the specificity of the IFA is estimated to be over 99\% (Johnston et al. 2003), with no cross-reaction with E. histolytica, Escherichia coli, Entamoeba hartmanii, Endolimax nana, and Chilomastix mesnili.

This study presents the first detection of ancient protozoan cysts using IFA in the Old World. The remarkable conservation conditions of the site and the presence of a humid and anaerobic environment favoured the preservation of parasitological remains and the discovery of intact cysts. The presence of $G$. intestinalis in $\mathrm{S} 1$ could reflect some sanitation problems and bad human and animal excrement management.

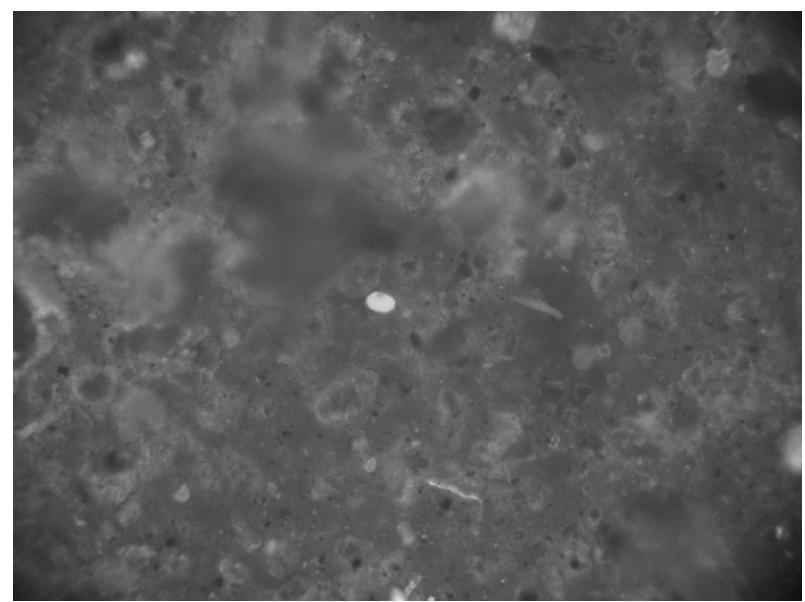

Fluorescent Giardia intestinalis cyst $(15 \times 8 \mu \mathrm{m})$ recovered at Pineuilh (original magnification, 400X).
This work also completes the parasitological records for the X-XI centuries AD medieval period, so completing a chronological hiatus in the European record of giardiasis. G. intestinalis cysts were recorded only in small numbers and in relatively recent archaeological sites in the Old World (VII-IX centuries AD) (Le Bailly 2005). This may contribute to debate the origin of the parasite strain in the New World, where G. intestinalis infection was recorded in Peruvian mummies dated to XXIV century BC (Ortega \& Bonavia 2003).

The use of IFA is particularly important in paleoparasitology, allowing the confirmation of some ELISA results, and thus decreasing false positive risks. Moreover, because of their specific ability in identifying parasitic remains, immunological tools present a major field in ancient parasite diagnostic. Systematic utilization of immunology should increase the species diversity detected in archaeological contexts, and will allow mapping the parasite historical records, clarifying ancient human migration pathways and human-parasite co-evolution.

\section{REFERENCES}

Acha PN, Szyfres B 2005. Zoonoses et maladies transmissibles communes à l'homme et aux animaux, 3rd ed., Vol. III, Office National des Epizooties, Paris, 399 pp.

Aldeen WE, Carroll K, Robinson A, Morrison M, Hale D 1998. Comparison of nine commercially available enzyme-linked immunosorbent assays for detection of Giardia lamblia in fecal specimens. J Clin Microbiol 36: 1338-1340.

Aldeen WE, Hale D, Robinson AJ, Carroll K 1995. Evaluation of a commercially available ELISA assay for detection of Giardia lamblia in fecal specimens. Parasitology 21: 77-79.

Allison MJ, Bergman T, Gerszten E 1999. Further studies on parasites in antiquity. Am J Clin Pathol 112: 605-609.

Boone JH, Wilkins TD, Nash TE, Brandon JE, Macias EA, Jerris RC, Lyerly DM 1999. TechLab and Alexon Giardia enzyme-linked immunosorbent assay kits detect cyst wall protein 1. J Clin $\mathrm{Mi}$ crobiol 37: 611-614.

Cerutti N, Marin A, Massa ER, Savoia D 1999. Immunological investigation of malaria and new perspectives in paleopathological studies. Boll Soc Ital Biol Sperim 75: 17-20.

Faulkner CT, Patton S, Johnson SS 1989. Prehistoric parasitism in Tennessee: evidence from the analysis of desiccated fecal material collected from Big Bone Cave, Van Buren County, Tennessee. J Parasitol 75: 461-463.

Fornaciari G, Castagna M, Viacava P, Tognetti A, Bevilacqua G, Segura EL 1992. Chagas disease in a Peruvian Inca mummy. Lancet 339: 128-129.

Fouant MM, Allison M, Gerszten E, Focacci G 1982. Parasitos intestinales entre los indigenas precolombinos. Rev Chungara 9: 285-299.

Garcia LS, Brewer TC, Bruckner DA 1987. Fluorescence detection of Cryptosporidium oocysts in human fecal specimens by using monoclonal antibodies. J Clin Microbiol 25: 119-121.

Gentilini M 1999. Médecine tropicale, 5th ed., Flammarion Médecine-Sciences, Paris, 950 pp.

Goncalves MLC, Araujo A, Duarte R, Pereira da Silva J, Reinhard K, Bouchet F, Ferreira LF 2002. Detection of Giardia duodenalis antigen in coprolites using a commercially available enzyme-linked immunosorbent assay. Trans R Soc Trop Med Hyg 96: 640-643.

Gonçalves MLC, Schnell C, Sianto L, Bouchet F, Le Bailly M, Rein- 
hard K, Ferreira LF, Araujo A 2005. Protozoan infection in archaeological material. J Biol Res 80: 146-148.

Goncalves MLC, Silva V, Andrade C, Rocha G, Le Bailly M, Bouchet F, Ferreira LF, Araujo A 2004. Amoebiasis distribution in the past: first steps in using an immunoassay technique. Trans $R$ Soc Trop Med Hyg 98: 88-91.

Johnston SP, Ballard MM, Beach MJ, Causer L, Wilkins PP 2003. Evaluation of three assays for the detection of Giardia and Cryptosporidium organisms in faecal specimens. J Clin Microbiol 41: 623-626.

Le Bailly M 2005. Evolution de la relation hôte/parasite dans les systèmes lacustres nord alpins au Néolithique (3900-2900 BC), et nouvelles données dans la détection des paléoantigènes de Protozoa, $\mathrm{PhD}$ Thesis, Université de Rims Champagne Ardenne, Reims, 291 pp.

LeBailly M, BouchetF2006. Paléoparasitologie et immunologie: l'exemple d'Entamoeba histolytica. Revue Archéométrie 30: 129-135.
Le Bailly M, Gonçalves MLC, Lefèvre C, Roper D, Pye JW, Araujo A, Bouchet F 2006. Parasitism in Kansas in the 1800s - A glimpse to the past through the analysis of grave sediments from Meadowlark cemetery. Mem Inst Oswaldo Cruz 101: 53-56.

Mehlhorn H 2001. Encyclopedic reference of Parasitology, 2nd ed., Springer, Berlin, $1350 \mathrm{pp}$.

Miller RL, Ikram S, Armelagos GJ, Walker R, Harer WB, Shiff CJ, Baggett D, Carrigan M, Maret SM 1994. Diagnosis of Plasmodium falciparum infections in mummies using the rapid manual ParaSight $^{\mathrm{TM}}$-F test. Trans $R$ Soc Trop Med Hyg 88: 31-32.

Nozais JP, Datry A, Danis M 1996. Traité de Parasitologie médicale, Pradel, Paris, 817 pp.

Ortega YR, Bonavia D 2003. Cryptosporidium, Giardia and Cyclospora in ancient Peruvians. J Parasitol 89: 635-636. 